\title{
PENGARUH PERSEPSI GENERASI LANGGAS TENTANG KUALITAS DAN INOVASI BATIK TERHADAP KEPUTUSAN PEMBELIAN DI ERA DIGITAL
}

\author{
Tisia Priskila \\ Manajemen, Universitas Bunda Mulia
}

Disetujui 9 Maret 2018

\begin{abstract}
Indonesia is experiencing serious problems in the era of globalization. Since the era of free trade, many imported products have flooded the national marketplace. Lack of domestic products' competition on its own country make business actors in Indonesia must understand about purchasing decision of millennial generations that will become the next generations of the nation. Their purchasing decision depends on the product quality perception and they want products that suit with their style. Millennial generations outreach through social media marketing is believed to be necessary to influence their purchasing decisions. The research objectives are to know the effect of the perception of modern Batik product quality and product innovation on purchasing decisions with social media marketing as a moderator variable. The analysis method used is Partial Least Square (PLS) with sample of 100 respondents. The research results show that the millennial generations' purchasing decisions are affected by their perception of product quality and innovation. The perception of product quality and purchasing decisions are weakened by social media marketing. The perception of product innovation and purchasing decisions are not affected by social media marketing as moderator variable.

Keywords: perception, quality, innovation, marketing, purchasing decision
\end{abstract}

\begin{abstract}
ABSTRAK
Indonesia sedang mengalami kendala yang cukup serius di era globalisasi ini. Semenjak diterapkan era perdagangan bebas, banyak produk dari luar negeri (impor) yang membanjiri pasar nasional. Kalah bersaingnya produk dalam negeri di negara sendiri membuat para pelaku bisnis di Indonesia harus paham mengenai dasar keputusan pembelian generasi muda langgas yang akan menjadi generasi penerus bangsa. Keputusan pembelian mereka bergantung kepada persepsi kualitas dan menginginkan inovasi produk yang sesuai dengan gaya mereka. Penjangkauan generasi langgas melalui pemasaran media sosial diyakini perlu dilakukan untuk memengaruhi keputusan pembelian mereka. Penelitian ini dilakukan dengan tujuan untuk mengetahui pengaruh persepsi generasi langgas tentang kualitas dan inovasi produk batik modern terhadap keputusan pembelian dengan pemasaran media sosial sebagai variabel moderator. Teknik analisis yang digunakan dalam penelitian ini adalah PLS (Partial Least Square) dengan sampel sebanyak 100 responden. Hasil penelitian menunjukkan bahwa keputusan pembelian dipengaruhi oleh persepsi kualitas dan inovasi produk. Persepsi kualitas produk dan keputusan pembelian diperlemah oleh pemasaran media sosial. Persepsi tentang inovasi produk dan keputusan pembelian tidak dipengaruhi oleh pemasaran media sosial sebagai variabel pemoderasi.
\end{abstract}

Kata kunci: persepsi, kualitas, inovasi, pemasaran, keputusan pembelian

\footnotetext{
*Korespondensi Penulis:

E-mail: tpriskila@bundamulia.ac.id
} 


\section{PENDAHULUAN}

Batik merupakan warisan budaya yang mengungkapkan ciri khas negara Indonesia. Akan tetapi, kesadaran untuk melestarikan dan menjaga keaslian budaya dalam negeri masih dipandang sebelah mata oleh generasi muda.

Indonesia sedang mengalami kendala yang cukup serius di era globalisasi ini. Semenjak diterapkan era perdagangan bebas, banyak produk dari luar negeri (impor) yang membanjiri pasar nasional. Kalah bersaingnya produk dalam negeri di negara sendiri membuat para pelaku bisnis di Indonesia harus paham mengenai dasar keputusan pembelian generasi muda langgas yang akan menjadi generasi penerus bangsa.

Keputusan pembelian diartikan sebagai perilaku yang timbul karena adanya rangsangan atau hubungan dari pihak lain (Kotler, 2011). Berbagai hal dapat memengaruhi keputusan konsumen untuk membeli atau tidak membeli suatu produk, salah satunya adalah cara memandang suatu produk (persepsi).

Hasil penelitian Yee et al. (2011) mengungkapkan bahwa adanya keterhubungan yang signifikan antara persepsi kualitas dengan keputusan pembelian. Penelitian mengungkapkan bahwa persepsi kualitas yang tinggi akan meningkatkan keputusan pembelian dikarenakan niat dari konsumen untuk membeli semakin kuat.

Keputusan pembelian generasi muda langgas terbentuk dari persepsi mereka bahwa produk asal luar negeri selalu memiliki kualitas yang lebih bagus dibanding produk dalam negeri. Generasi langgas cenderung lebih bangga jika memakai merek tertentu, sehingga mereka lebih senang mengonsumsi produk-produk luar negeri.

Memasuki era generasi muda langgas saat ini, salah satu yang dapat memengaruhi keputusan pembelian produk adalah dengan melakukan inovasi produk. Dahulu, batik hanya dipakai untuk kalangan-kalangan tertentu. Banyak generasi muda menganggap produk batik masih kuno, monoton, dan tidak sesuai dengan gaya kalangan muda. Akan tetapi, beralihnya jaman membuat pengrajin batik mulai berlomba-lomba membuat inovasi batik modern yang terkesan lebih kasual dan stylist untuk membuat generasi anakanak muda langgas mencintai batik produksi dalam negeri.

Beralih dari model batik yang terkesan kaku, kini pengrajin batik membuat inovasi terbaru. Dari segi fashion, saat ini batik sudah bertransformasi menjadi baju kasual dan memiliki model kekinian. Batik juga sekarang tidak hanya ditemui pada produk baju, tetapi sekarang sudah merambat menjadi bentuk aksesoris bernuansa batik seperti anting-anting, sepatu, sandal, sarung handphone, maupun tas.

Generasi langgas adalah generasi muda yang nyaris tanpa sekat soal informasi. Mereka tidak bisa dipisahkan dari teknologi gawai seperti smartphone, tablet, ataupun laptop. Media sosial bukan hanya sekedar sebagai sarana berinteraksi tetapi juga menjadi sumber informasi, berita, bahkan media pencarian suatu produk atau jasa. Keputusan pembelian mereka terhadap suatu produk atau jasa juga didasarkan pada referensi teman atau orang lain yang mereka baca melalui media sosial. Pemasar atau pelaku bisnis perlu memikirkan strategi pemasaran yang tepat untuk menjangkau mereka dan memengaruhi keputusan mereka untuk membeli suatu produk.

Oleh sebab itu, penelitian ini dilakukan dengan tujuan untuk mengetahui pengaruh persepsi generasi langgas tentang kualitas dan inovasi produk batik modern terhadap keputusan pembelian, serta pengaruh pemasaran media sosial sebagai variabel moderator terhadap persepsi kualitas, inovasi produk, dan keputusan pembelian generasi langgas. 


\section{TINJAUAN PUSTAKA}

\section{Penelitian Terdahulu}

Penelitian yang pernah dilakukan oleh Yee et al. (2011) dan Kandasamy (2014) menunjukkan bahwa adanya pengaruh persepsi kualitas produk terhadap keputusan pembelian konsumen. Artinya, semakin tinggi persepsi konsumen atas kualitas produk, maka tingkat keputusan pembelian konsumen akan semakin tinggi.

Dalam penelitian yang dilakukan oleh Munifah, dkk (2014); Umaternate, dkk (2014) menunjukkan bahwa ada pengaruh inovasi produk terhadap keputusan pembelian. Artinya, semakin baik inovasi produk maka semakin tinggi pengaruhnya terhadap keputusan pembelian konsumen.

Penelitian yang dilakukan oleh Yogesh dan Yesha (2014); Khatib (2016) menemukan hasil bahwa adanya pengaruh media sosial terhadap keputusan pembelian. Media sosial berfungsi sebagai alat perbandingan informasi, rekomendasi, dan ketersediaan ulasan yang membantu konsumen dalam proses keputusan pembelian. Ulasan orang lain di dalam media sosial memengaruhi proses keputusan pembelian konsumen, bisa mendorong ataupun mencegah pembelian.

\section{Kualitas Produk}

Kualitas produk adalah kemampuan sebuah produk dalam memeragakan fungsinya. Hal ini termasuk keseluruhan durabilitas, reliabilitas, ketepatan, kemudahan pengoperasian, dan reparasi produk, juga atribut produk lainnya (Kotler dan Armstrong, 2012).

Kualitas produk dapat dimasukkan ke dalam 9 dimensi yaitu: bentuk (form), ciri-ciri produk (features), kinerja (performance), kesesuaian (conformance), ketahanan (durability), kehandalan (reliability), kemudahan perbaikan (repairability), gaya (style), dan desain (design).

\section{Persepsi Kualitas \\ Persepsi kualitas merupakan penilaian pelanggan terhadap keunggulan}

atau superioritas produk secara keseluruhan (Tjiptono, 2005). Persepsi kualitas didasarkan pada evaluasi subyektif konsumen terhadap kualitas produk. Persepsi kualitas biasanya didasarkan pada dimensi-dimensi yang termasuk dalam karakteristik kualitas produk seperti kehandalan, ketahanan, dan sebagainya.

\section{Inovasi Produk}

Inovasi berasal dari kata to innovate yang mempunyai arti membuat perubahan atau memperkenalkan sesuatu yang baru. Inovasi produk meliputi berbagai kegiatan pengembangan produk dan perbaikan produk, pengembangan yang seluruhnya baru, dan perluasan yang meningkatkan jangkauan atau jumlah lini produk yang dapat ditawarkan perusahaan. Sebuah inovasi didefinisikan sebagai suatu ide, produk, atau bagian dari teknologi yang telah dikembangkan dan dipasarkan untuk pelanggan yang dirasa sebagai sesuatu yang baru (Kotler dan Armstrong, 2012). Inovasi produk perlu dilakukan oleh perusahaan atau pelaku usaha agar dapat menarik minat konsumen, tetap bertahan, dan menjadi lebih kompetitif.

\section{Pemasaran Media Sosial}

Media sosial didefinisikan sebagai sarana bagi konsumen untuk berbagi informasi teks, gambar, audio, dan video dengan satu sama lain dan dengan perusahaan dan sebaliknya (Kotler dan Keller, 2012).

Pemasaran media sosial (social media marketing) adalah bentuk pemasaran langsung atau tidak langsung yang digunakan untuk membangun kesadaran, pengakuan, ingat, dan tindakan untuk merek, bisnis, produk, orang, atau badan lain dan dilakukan dengan menggunakan alat-alat dari Web sosial seperti blogging, jejaring sosial, bookmark sosial, dan konten (Gunelius, 2011).

\section{Keputusan Pembelian}

Keputusan pembelian adalah proses keputusan pembelian terdiri dari lima tahap yang dilakukan oleh seorang konsumen 
sebelum sampai pada keputusan pembelian dan selanjutnya pasca pembelian (Kotler dan Keller, 2012).

Menurut Kotler dan Armstrong (2012), konsumen akan melewati lima tahap proses keputusan pembelian yaitu: pengenalan kebutuhan, pencarian informasi, evaluasi alternatif, keputusan pembelian, dan perilaku pasca pembelian.

\section{Model Penelitian}

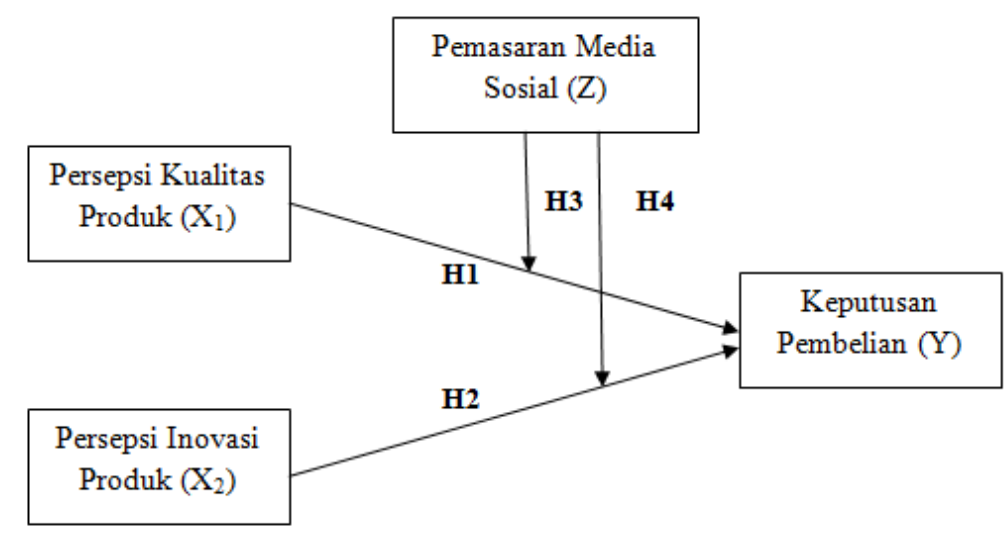

Gambar 1. Model Penelitian

Sumber: Peneliti

\section{Hipotesis}

1. Keputusan pembelian generasi langgas dipengaruhi oleh persepsi tentang kualitas produk batik modern.

2. Keputusan pembelian generasi langgas dipengaruhi oleh persepsi tentang inovasi produk batik modern.

3. Pengaruh persepsi kualitas produk batik modern terhadap keputusan pembelian generasi langgas dipengaruhi oleh pemasaran media sosial sebagai variabel pemoderasi.

4. Pengaruh persepsi inovasi produk batik modern terhadap keputusan pembelian generasi langgas dipengaruhi oleh pemasaran media sosial sebagai variabel pemoderasi.

\section{METODE PENELITIAN}

\section{Jenis dan Sumber Data Penelitian}

Jenis penelitian ini adalah penelitian deskriptif dengan pendekatan kuantitatif. Sumber data penelitian ini yaitu data primer (wawancara dan kuesioner terstruktur) dan data sekunder (studi kepustakaan, jurnal, literatur, serta penelusuran Internet).

\section{Populasi dan Sampel}

Populasi dalam penelitian ini adalah generasi langgas yang pernah membeli batik modern.

Sampel dalam penelitian ini adalah 100 orang responden. Cara penentuan sampel adalah dengan mengalikan aturan minimal dalam metode PLS sebanyak 5 (lima) dengan jumlah indikator yang digunakan sebanyak 20 buah indikator (masing-masing peubah memiliki lima indikator).

\section{Metode Analisis Data}

Metode analisis data menggunakan Partial Least Squares (PLS) dengan bantuan program SmartPLS 3.0. Model PLS dilakukan dengan mengevaluasi model 
pengukuran (outer model) dan model struktural (inner model).

Penilaian model pengukuran (outer model) bertujuan menguji validitas konstruk dan reliabilitas instrumen. Untuk uji validitas konstruk digunakan metode convergent validity dan discriminant validity sedangkan untuk uji reliabilitas digunakan metode Composite Reliability dan Cronbach's Alpha.

Hasil akhir dari pengujian model struktural (inner model) serta signifikansi model dilakukan dengan menggunakan metode bootstrap (metode non-parametric) dikarenakan PLS tidak menggunakan asumsi data terdistribusi normal (Hair et al.,
2014). Hasil uji signifikansi inilah yang nanti akan dijadikan sebagai dasar pengujian hipotesis penelitian.

Untuk melihat besarnya keterubahan peubah keputusan pembelian dapat dilihat melalui koefisien determinasi.

\section{HASIL DAN PEMBAHASAN}

\section{Karakteristik Responden}

Adapun karakteristik 100 orang responden dalam penelitian ini telah dirangkum dalam Tabel 1.

Tabel 1. Karakteristik Responden Penelitian

\begin{tabular}{|c|c|c|c|}
\hline No. & Profil & Kategori & $\begin{array}{c}\text { Persentase } \\
(\%)\end{array}$ \\
\hline \multirow[t]{2}{*}{1} & Gender & Laki-laki & 29 \\
\hline & & Perempuan & 71 \\
\hline \multirow[t]{3}{*}{2} & Pendidikan Terakhir & SMA & 19 \\
\hline & & S1 & 67 \\
\hline & & S2 & 14 \\
\hline \multirow[t]{4}{*}{3} & Pekerjaan & Ibu Rumah Tangga & 7 \\
\hline & & Karyawan Swasta & 79 \\
\hline & & PNS & 3 \\
\hline & & Wirausaha & 11 \\
\hline \multirow[t]{7}{*}{4} & Produk Batik yang Diketahui & Aksesoris (anting, kalung, gelang) & 9.9 \\
\hline & & Dompet & 17.8 \\
\hline & & Fashion (baju dan celana) & 24.8 \\
\hline & & Sarung Handphone & 12.9 \\
\hline & & Sepatu & 12.6 \\
\hline & & Tas & 21 \\
\hline & & Topi & 1 \\
\hline \multirow[t]{3}{*}{5} & Tingkat Keseringan Melakukan Pembelian & Pernah (1 kali) & 22 \\
\hline & Batik & Kadang-kadang (2-4 kali) & 65 \\
\hline & & Sering (lebih dari 4 kali) & 13 \\
\hline \multirow[t]{3}{*}{6} & Tempat Pembelian Batik & Offline Shopping & 27 \\
\hline & & Online Shopping & 9 \\
\hline & & Offline dan Online Shopping & 64 \\
\hline \multirow[t]{3}{*}{7} & Rentang Harga Batik yang Dibeli & Murah (dibawah Rp.200.000) & 25 \\
\hline & & Rata-Rata (Rp.200.000 - Rp. 499.000) & 73 \\
\hline & & Mahal (diatas Rp. 500.000) & 2 \\
\hline \multirow[t]{8}{*}{8} & Jenis Media Sosial yang Digunakan & Blogspot & 7.7 \\
\hline & & Blogwalking & 7.1 \\
\hline & & Facebook & 19.4 \\
\hline & & Instagram & 44.4 \\
\hline & & Line & 3.6 \\
\hline & & Twitter & 1.5 \\
\hline & & Whatsapp & 7.1 \\
\hline & & Youtube & 9.2 \\
\hline \multirow[t]{2}{*}{9} & Tingkat Keseringan Pemanfaatan Media & Kurang dari 2 kali & 2 \\
\hline & Sosial & Lebih dari 2 kali & 98 \\
\hline
\end{tabular}




\section{Analisis Statistik Deskriptif}

\section{Persepsi Kualitas Produk}

Nilai rerata yang diperoleh melalui seluruh indikator penelitian adalah sebesar 3,80 (kategori setuju) menunjukkan bahwa generasi langgas berpersepsi baik terhadap kualitas produk batik modern saat ini.

Nilai indikator yang paling besar dari variabel persepsi kualitas produk adalah kenyamanan produk batik modern dengan rata-rata skor sebesar 4,00. Nilai indikator yang paling kecil dari variabel persepsi kualitas produk adalah ketahanan produk batik modern dengan rata-rata skor sebesar 3,60.

\section{Persepsi Inovasi Produk}

Nilai rerata yang diperoleh melalui seluruh indikator penelitian adalah sebesar 4,24 (kategori sangat setuju) menunjukkan bahwa generasi langgas berpersepsi sangat baik terhadap inovasi produk batik modern saat ini.

Nilai indikator yang paling besar dari variabel persepsi inovasi produk adalah keanekaragaman produk dengan rata-rata skor sebesar 4,44. Nilai indikator yang paling kecil dari variabel persepsi inovasi produk adalah desain yang lebih baik dengan rata-rata skor sebesar 4,01.

\section{Pemasaran Media Sosial}

Nilai rerata yang diperoleh melalui seluruh indikator penelitian adalah sebesar 4,30 (kategori sangat setuju) menunjukkan bahwa pemasaran melalui media sosial sangat berpengaruh bagi generasi langgas sebelum mereka memutuskan untuk melakukan pembelian produk.

Nilai indikator yang paling besar dari variabel pemasaran media sosial adalah penggunaan smartphone dalam mencari informasi terkait produk dengan rata-rata skor sebesar 4,41. Nilai indikator yang paling kecil dari variabel pemasaran media sosial adalah iklan di jejaring sosial dengan rata-rata skor sebesar 4,16.

\section{Keputusan Pembelian}

Nilai rerata yang diperoleh melalui seluruh indikator penelitian adalah sebesar 4,20 (kategori setuju).

Nilai indikator yang paling besar dari variabel keputusan pembelian adalah pemutusan pembelian karena pelestarian budaya dengan rata-rata skor sebesar 4,36. Nilai indikator yang paling kecil dari variabel keputusan pembelian adalah pemutusan pembelian karena kualitas produk batik modern dengan rata-rata skor sebesar 4,09.

\section{Analisis Statistik Inferensial}

\section{Mode7l Pengukuran (Outer Model)}

Uji validitas outer model dilakukan dengan menggunakan validitas konvergen dan validitas diskriminasi. Penilaian validitas konvergen dilakukan dengan melihat nilai AVE (AVE $\geq 0,50$ dikatakan valid).

Tabel 2. Nilai AVE

\begin{tabular}{ll}
\hline \multicolumn{1}{c}{ Variabel } & AVE \\
\hline Persepsi Kualitas Produk & 0,566 \\
\hline Persepsi Inovasi Produk & 0,583 \\
\hline Pemasaran Media Sosial & 0,534 \\
\hline Keputusan Pembelian & 0,538 \\
\hline Sumber: Hasil Pengolahan Smart PLS 3.0 &
\end{tabular}

Tabel 2 menunjukkan hasil AVE yang didapat nilainya di atas 0,50 sehingga dapat dinyatakan indikator penelitian telah memenuhi kriteria validitas.
Uji reliabilitas indikator dalam PLS dinilai berdasarkan nilai loading factor indikator yang mengukur konstruk tersebut. Dikatakan reliabel apabila nilai loading factor $\geq 0,40$ (Hair et al., 2011). 


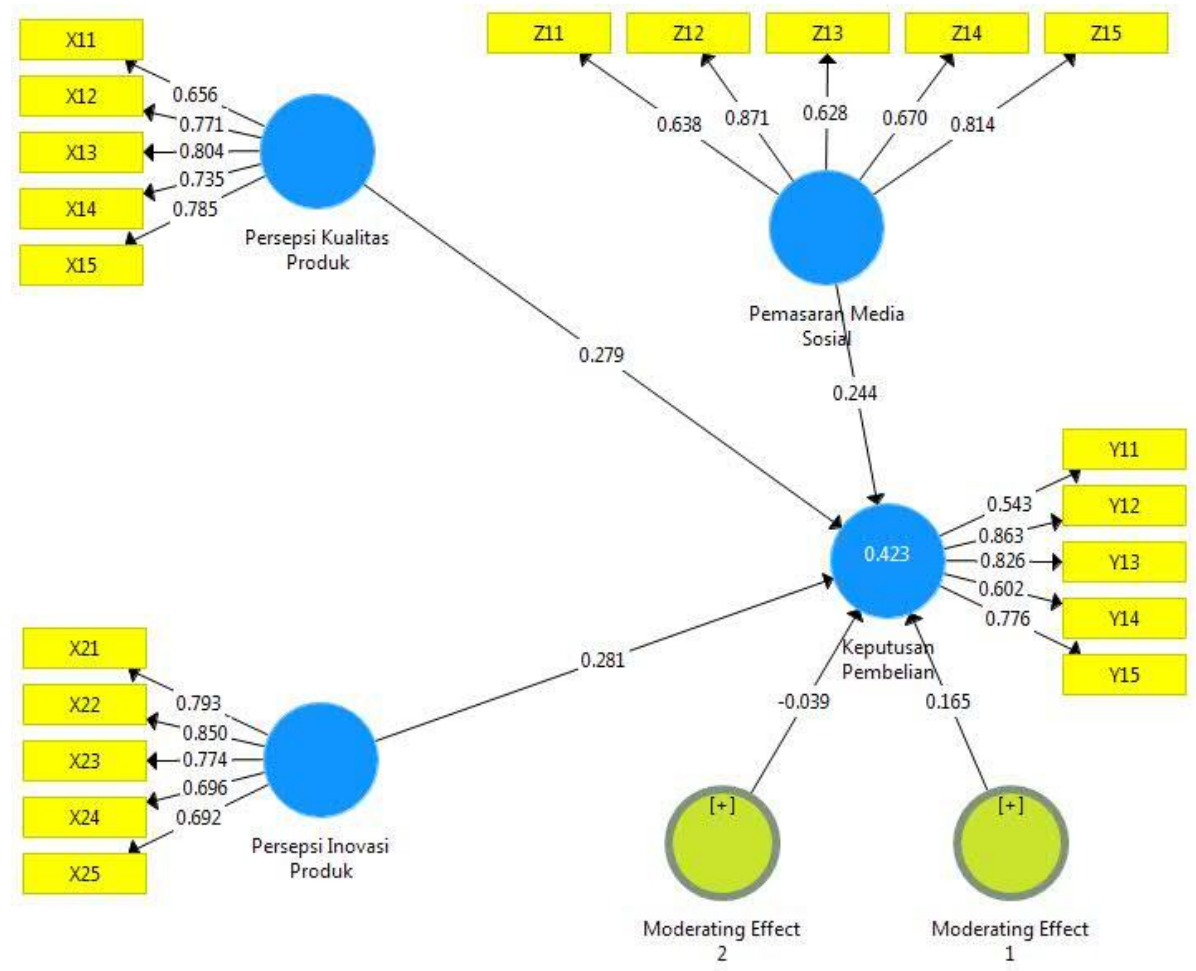

Gambar 2. Loading Factor

Sumber: Hasil Pengolahan Smart PLS 3.0

Gambar 2 menunjukkan bahwa seluruh indikator sudah memiliki nilai muatan faktor lebih besar dari 0,4 (indikator telah memenuhi kriteria reliabilitas).

Pengujian reliabilitas konstruk dapat dilakukan dengan metode composite reliability dan koefisien Alpha Cronbach. Dikatakan reliabel jika nilai composite reliability $\geq 0,70$ dan nilai koefisien Alpha Cronbach $\geq 0,60$ (Hair et al., 2011)

\section{Tabel 3. Nilai Reliabilitas Konstruk}

\begin{tabular}{lcc}
\multicolumn{1}{c}{ Variabel } & Composite Reliability & Cronbach's Alpha \\
Persepsi Kualitas Produk & 0,866 & 0,810 \\
Persepsi Inovasi Produk & 0,874 & 0,819 \\
Pemasaran Media Sosial & 0,849 & 0,798 \\
Keputusan Pembelian & 0,849 & 0,780 \\
\hline
\end{tabular}

Sumber: Hasil Pengolahan Smart PLS 3.0

Tabel 3 menunjukkan bahwa nilai composite reliability untuk semua konstruk berada di atas 0,70 dan nilai koefisien Alpha Cronbach untuk semua konstruk berada di atas 0,60 , sehingga telah memenuhi kriteria reliabilitas.

\section{Model Struktural (Inner Model)}

\section{Koefisien Determinasi}

Koefisien determinasi $\left(\mathrm{R}^{2}\right)$ digunakan untuk melihat seberapa besar keterubahan peubah gayut akibat peubah bebas. 
Tabel 4. Koefisien Determinasi

\begin{tabular}{lcc}
\hline \multicolumn{1}{c}{ Variabel } & R Square & R Square Adjusted \\
\hline Keputusan Pembelian & 0,423 & 0,393 \\
\hline Sumber: Hasil Pengolahan Smart PLS 3.0 & &
\end{tabular}

Tabel 4 menunjukkan bahwa pengaruh persepsi generasi langgas tentang kualitas produk dan inovasi produk secara bersama-sama terhadap keterubahan keputusan pembelian batik modern adalah sebesar 39,3\%. Sisanya, sebanyak $60,7 \%$ dijelaskan oleh variabel lain di luar penelitian.
Pengujian hipotesis dilakukan dengan melihat nilai koefisien jalur yang menunjukkan tingkat signifikansi. Skor koefisien jalur atau inner model yang ditunjukkan oleh nilai t-statistic harus lebih besar dari nilai t-tabel pengujian dua arah $(>1,98)$ dengan $\alpha=5 \%$. Hasil bootstrap dapat dilihat pada Gambar 3 dan terangkum dalam Tabel 5.

\section{Uji Hipotesis}

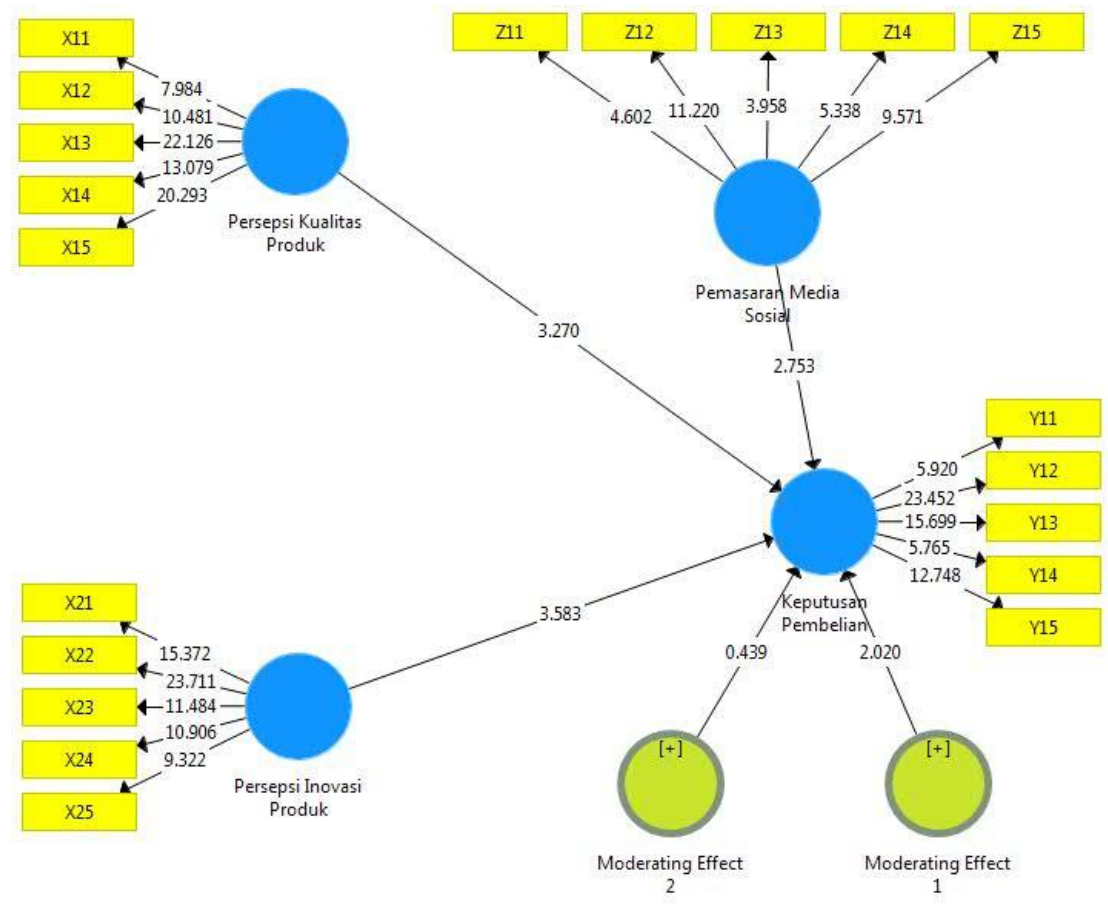

Gambar 3. Hasil Bootstrap Model Variabel Laten

Sumber: Hasil Pengolahan Smart PLS 3.0 
Tabel 5. Hasil Pengujian Hipotesis

\begin{tabular}{|c|c|c|c|c|c|}
\hline & Hipotesis & $\begin{array}{c}\text { Koefisien } \\
\text { Jalur }\end{array}$ & $\begin{array}{c}\text { t-statistics } \\
>1,98 \\
\end{array}$ & $\begin{array}{c}\text { Sig. } \\
<0,05 \\
\end{array}$ & Hasil \\
\hline H1 & $\begin{array}{l}\text { Keputusan pembelian } \\
\text { generasi langgas } \\
\text { dipengaruhi oleh persepsi } \\
\text { tentang kualitas produk } \\
\text { batik modern. }\end{array}$ & 0,279 & 3,270 & 0,001 & Diterima \\
\hline H2 & $\begin{array}{l}\text { Keputusan pembelian } \\
\text { generasi langgas } \\
\text { dipengaruhi oleh persepsi } \\
\text { tentang inovasi produk batik } \\
\text { modern. }\end{array}$ & 0,281 & 3,583 & 0,000 & Diterima \\
\hline H3 & $\begin{array}{l}\text { Pengaruh persepsi kualitas } \\
\text { produk batik modern } \\
\text { terhadap keputusan } \\
\text { pembelian generasi langgas } \\
\text { dipengaruhi oleh pemasaran } \\
\text { media sosial sebagai } \\
\text { variabel pemoderasi. }\end{array}$ & 0,165 & 2,020 & 0,022 & Diterima \\
\hline H4 & $\begin{array}{l}\text { Pengaruh persepsi inovasi } \\
\text { produk batik modern } \\
\text { terhadap keputusan } \\
\text { pembelian generasi langgas } \\
\text { dipengaruhi oleh pemasaran } \\
\text { media sosial sebagai } \\
\text { variabel pemoderasi. }\end{array}$ & $-0,039$ & 0,439 & 0,330 & Ditolak \\
\hline
\end{tabular}

Sumber: Hasil Pengolahan Smart PLS 3.0

Tabel 5 menunjukkan bahwa hipotesis pertama (H1) memiliki nilai t-hitung sebesar 3,270 $(>1,98)$ dan nilai signifikansi sebesar 0,001 $(<0,05)$. Dengan demikian, H1 diterima. Hipotesis kedua (H2) memiliki nilai t-hitung sebesar 3,583 $(>1,98)$ dan nilai signifikansi sebesar 0,000 $(<0,05)$. Dengan demikian, H2 diterima. Hipotesis ketiga (H3) memiliki nilai t-hitung sebesar 2,020 $(>1,98)$ dan nilai signifikansi sebesar $0,022 \quad(<0,05)$. Dengan demikian, H3 diterima. Hipotesis keempat (H4) memiliki nilai t-hitung sebesar 0,439 $(<1,98)$ dan nilai signifikansi sebesar 0,330 $(>0,05)$. Dengan demikian, H4 ditolak.

\section{Pembahasan}

\section{Persepsi Kualitas Produk Terhadap Keputusan Pembelian}

Hasil penelitian menunjukkan bahwa keputusan pembelian generasi langgas dipengaruhi secara positif oleh persepsi tentang kualitas produk batik modern (sig 0,001 <0,05). Artinya, ketika generasi langgas berpersepsi produk batik modern memiliki kualitas yang baik maka tingkat keputusan pembelian mereka terhadap produk batik modern akan meningkat. Sebaliknya, ketika generasi langgas berpersepsi produk batik modern memiliki kualitas yang buruk maka tingkat keputusan pembelian mereka terhadap produk batik modern akan menurun.

Hasil penelitian ini sejalan dengan penelitian Choy Johnn Yee dan Ng Cheng San (2011) yang mengungkapkan adanya 
keterhubungan yang signifikan antara persepsi tentang kualitas produk dan keputusan pembelian.

Hasil analisis statistik deskriptif variabel persepsi kualitas produk menunjukkan bahwa rata-rata responden berpersepsi bahwa produk Batik modern saat ini telah memiliki kualitas yang baik yang memengaruhi tingkat keputusan pembelian mereka. Jika dilihat dari karakteristik responden berdasarkan rentang harga produk batik modern yang dibeli, mayoritas responden (73\%) membeli produk batik modern dengan rentang harga Rp. 200.000 hingga Rp. 499.000. Mereka merasa kualitas produk batik modern di rentang harga tersebut sudah sesuai dengan standar kualitas yang telah ditetapkan, memiliki bahan yang nyaman untuk digunakan, tahan lama, dan sudah sesuai dengan spesifikasi yang mereka harapkan. Tetapi ada sebagian kecil responden yang membeli produk fashion (baju dan celana) dengan harga yang tergolong murah (di bawah Rp. 200.000) berpendapat bahwa produk batik modern tersebut belum memiliki bahan yang nyaman untuk dipakai (tidak mudah menyerap keringat), tidak begitu awet atau tahan lama (susut dan luntur ketika dicuci), warnanya pudar jika dipakai terus menerus, dan jahitannya kurang rapi. Hal ini bisa memengaruhi keputusan pembelian mereka selanjutnya.

\section{Persepsi Inovasi Produk Terhadap Keputusan Pembelian}

Hasil penelitian menunjukkan

bahwa keputusan pembelian generasi langgas dipengaruhi oleh persepsi tentang inovasi produk batik modern (sig 0,000 < $0,05)$. Artinya, ketika generasi langgas berpersepsi produk batik modern saat ini inovatif maka tingkat keputusan pembelian mereka terhadap produk batik modern akan meningkat. Sebaliknya, ketika generasi langgas berpersepsi produk batik modern saat ini tidak inovatif, maka tingkat keputusan pembelian mereka terhadap produk batik modern akan menurun. Hasil penelitian ini sejalan dengan penelitian Nur
Munifah, Endah Pri Ariningsih, dan Wijayanti (2014) yang mengungkapkan adanya pengaruh inovasi produk terhadap keputusan pembelian.

Hasil analisis statistik deskriptif variabel persepsi inovasi produk menunjukkan bahwa rata-rata responden berpersepsi bahwa produk Batik modern saat ini inovatif dan memiliki variasi produk. Seperti yang diketahui bahwa dulu produk batik hanya sebatas baju, kain, dan sarung, tetapi sekarang sudah beraneka ragam. Hal ini terbukti dari berbagai jenis produk batik yang diketahui dan dibeli oleh generasi langgas mulai dari aksesoris (anting, kalung, gelang), dompet, fashion (baju dan celana), sarung handphone, sepatu, tas, dan topi yang bercorak batik. Selain itu, mereka merasa desain produk batik modern telah mengikuti tren jaman sekarang (kekinian), sesuai dengan gaya mereka sebagai generasi langgas, inovasi desainnya jauh lebih baik dari sebelumnya, dan unik.

Tetapi, ada sebagian kecil responden yang merasa desain produk batik modern masih kurang inovatif terutama di produk fashion (baju dan celana) yang menurut mereka masih terkesan seperti baju untuk kerja dan tidak bisa dipakai ke mall atau berpergian. Hal ini bisa memengaruhi keputusan pembelian mereka selanjutnya.

\section{Pengaruh Pemasaran Media Sosial sebagai Variabel Pemoderasi Terhadap Persepsi Kualitas Produk dan Keputusan Pembelian}

Hasil penelitian menunjukkan bahwa persepsi kualitas produk batik modern dan keputusan pembelian generasi langgas dipengaruhi oleh pemasaran media sosial sebagai variabel pemoderasi (sig. $0,022<0,05$ ). Tetapi pengaruh pemasaran media sosial sebagai variabel pemoderasi memperlemah persepsi kualitas produk dan keputusan pembelian (dari koefisien jalur 0,279 menjadi 0,165 ).

Persepsi yang baik tentang kualitas suatu produk terjadi karena kualitas produk yang ditawarkan melebihi ekspektasi atau harapan dari pelanggan. Berdasarkan hasil 
pengamatan peneliti, generasi langgas adalah generasi yang tanpa sekat soal informasi dan tidak pernah terlepas dari media sosial. Generasi langgas menganggap media sosial sebagai alat perbandingan antara informasi dan persepsi mereka terhadap suatu produk. Informasi tentang suatu produk dari media sosial bisa didapat dari pencarian atau penelusuran Internet melalui smartphone, komunikasi dengan penjual, iklan dan promosi di media sosial, serta ulasan atau review dari orang lain di media sosial. Ketika informasi yang generasi langgas dapatkan dari media sosial tidak sesuai dengan persepsi mereka tentang kualitas suatu produk maka hal tersebut akan memperlemah tingkat keputusan pembelian.

Jika dilihat dari karakteristik responden berdasarkan tingkat keseringan pemanfaatan media sosial, terbukti bahwa 98\% responden menggunakan media sosial lebih dari 2 kali dalam sehari. Hasil analisis statistik deskripstif variabel pemasaran media sosial menunjukkan bahwa generasi langgas akan menggunakan smartphone mereka terlebih dahulu untuk mencari informasi tentang produk dan akan berkomunikasi terlebih dahulu dengan penjual melalui media sosial untuk mencari informasi sebelum memutuskan untuk membeli produk. Ketika informasi yang mereka dapatkan dari media sosial terkait jenis bahan atau kualitas produk batik modern atau gambar yang ada di media sosial tidak sesuai dengan persepsi awal mereka terkait kualitas produk batik modern yang baik, maka hal tersebut akan memperlemah keyakinan mereka dalam memutuskan untuk membeli produk batik modern tersebut.

Menurut pendapat beberapa responden dalam penelitian ini, iklan dan promosi serta pemberian kupon diskon atau voucher di media sosial terkait produk batik modern masih sangat kurang. Jika dilihat dari karakteristik responden berdasarkan jenis media sosial yang digunakan, mayoritas responden (sebesar 44,4\%) menggunakan media sosial Instagram. Di Instagram masih sangat jarang terlihat iklan atau promosi mengenai produk batik modern.

Selain itu, generasi langgas yang lahir di era digital ini terbiasa untuk melihat ulasan atau review dari orang lain terlebih dahulu sebelum memutuskan untuk membeli produk. Jika dilihat dari karakteristik responden berdasarkan tempat pembelian batik, generasi langgas sudah mulai beralih untuk membeli di online shopping. Review yang buruk atau negatif dari orang lain akan memperlemah keputusan pembelian dari generasi langgas yang sebelumnya berpersepsi bahwa kualitas produk batik modern baik, apalagi jika responden tersebut berniat untuk membeli produk batik modern di online shop (tidak melihat kualitas produknya secara langsung). Ini menjadi tantangan bagi produsen Batik Modern ke depannya terkait bagaimana cara membuat konsumen memberikan ulasan yang positif di media sosial terkait kualitas produk yang bisa memperkuat persepsi konsumen akan suatu produk.

\section{Pengaruh Pemasaran Media Sosial sebagai Variabel Pemoderasi Terhadap Persepsi Inovasi Produk dan Keputusan Pembelian \\ Hasil penelitian menunjukkan} bahwa persepsi inovasi produk batik modern dan keputusan pembelian generasi langgas tidak dipengaruhi oleh pemasaran media sosial sebagai variabel pemoderasi (sig. 0,330>0,05).

Generasi langgas adalah generasi yang menyukai perbedaan dan keunikan. Ketika mereka berpersepsi bahwa produk batik modern yang ingin mereka beli unik (tidak bisa ditemukan di tempat lain) dan sudah sesuai dengan gaya mereka maka mereka sudah tidak peduli lagi dengan informasi dan promosi yang mereka dapatkan dari media sosial. Oleh sebab itu, ketika mereka mendapatkan informasi yang tidak sesuai, review orang lain yang buruk, iklan atau promosi yang kurang, maka keputusan mereka untuk membeli produk batik modern tersebut akan tetap sama. 


\section{SIMPULAN DAN SARAN}

\section{Simpulan}

Hasil penelitian yang dapat disimpulkan sebagai berikut :

1. Keputusan pembelian generasi langgas dipengaruhi oleh persepsi tentang kualitas produk batik modern. Artinya, ketika generasi langgas berpersepsi produk batik modern memiliki kualitas yang baik maka tingkat keputusan pembelian mereka terhadap produk batik modern akan meningkat dan sebaliknya, ketika generasi langgas berpersepsi produk batik modern memiliki kualitas yang buruk maka tingkat keputusan pembelian mereka terhadap produk batik modern akan menurun.

2. Keputusan pembelian generasi langgas dipengaruhi oleh persepsi tentang inovasi produk batik modern. Artinya, ketika generasi langgas berpersepsi produk batik modern saat ini inovatif maka tingkat keputusan pembelian mereka terhadap produk batik modern akan meningkat dan sebaliknya, ketika generasi langgas berpersepsi produk batik modern saat ini tidak inovatif maka tingkat keputusan pembelian mereka terhadap produk batik modern akan menurun.

3. Persepsi tentang kualitas produk batik modern dan keputusan pembelian generasi langgas dipengaruhi oleh pemasaran media sosial sebagai variabel pemoderasi. Tetapi pengaruh pemasaran media sosial sebagai variabel moderator memperlemah pengaruh persepsi kualitas produk terhadap keputusan pembelian.

4. Persepsi tentang inovasi produk batik modern dan keputusan pembelian generasi langgas tidak terdampak oleh pemasaran media sosial sebagai variabel pemoderasi. Ketika mereka berpersepsi bahwa produk batik modern yang ingin mereka beli unik (tidak bisa ditemukan di tempat lain) dan sudah sesuai dengan gaya mereka, maka mereka sudah tidak peduli lagi dengan informasi dan promosi yang mereka dapatkan dari media sosial.

\section{Saran}

Saran yang bisa diberikan berdasarkan hasil penelitian ini adalah sebagai berikut:

1. Produsen batik modern sebaiknya lebih meningkatkan lagi kualitas kain atau bahan batik saat ini terutama untuk produk batik dengan rentang harga murah karena banyak dijumpai produk batik terutama jenis fashion (baju dan celana) luntur ketika dicuci, warnanya cepat pudar, jahitan kurang rapi, dan tidak tahan lama. Hal ini juga bisa memengaruhi pemasaran media sosial secara tidak langsung terkait ulasan atau review dari orang lain yang pernah membeli produk batik. Generasi langgas adalah generasi yang mudah terpengaruh dengan informasi yang mereka dapatkan dari media sosial. Ketika kualitas kain atau bahan produk batik modern bagus maka ulasan pembeli di media sosial akan menjadi baik dan secara tidak langsung akan menggeser pandangan generasi langgas tentang kualitas produk batik modern saat ini.

2. Produsen batik modern sebaiknya lebih berinovasi lagi untuk desain produk yang lebih baik, seperti produk fashion lebih bisa dibuat lebih bermodel sehingga tidak terkesan seperti baju kerja. Akibatnya, generasi langgas menjadi tertarik untuk memakai produk batik ke luar negeri atau pun mall (saat mereka berpergian) tanpa mengurangi nilai dari budaya batik itu sendiri.

3. Produsen batik modern sebaiknya lebih meningkatkan lagi jenis corak batik karena Indonesia memiliki beragam suku dan provinsi dan setiap provinsi memiliki khas corak batik yang berbeda. Alangkah baiknya jika produsen menggali lebih dalam lagi tentang corak batik daerah lain dan semakin meningkatkan inovasi corak batik.

4. Pemerintah sebaiknya memberikan kebijakan memakai produk batik di 
sekolah dan tempat kerja minimal dua hari dalam seminggu untuk menanamkan rasa mencintai budaya Indonesia sejak dini. Selain itu, pemerintah sebaiknya memberikan informasi atau pelajaran terkait budaya batik yang ada di Indonesia ke generasi muda supaya mereka mengerti apa arti dibalik batik dan semakin meningkatkan rasa ingin melestarikan budaya Indonesia bahkan memperkenalkan budaya Indonesia ke mancanegara.

5. Penelitian selanjutnya sebaiknya meneliti tentang variabel-variabel lain seperti harga yang bisa menjadi variabel inti yang menyebabkan keterubahan yang tinggi terhadap keputusan pembelian generasi langgas.

\section{DAFTAR PUSTAKA}

Gunelius, S. (2011). 30 Minutes Social Media Marketing: Step by Step Techniques to Spread the Words about Your Business. USA: McGraw Hill.

Hair, Joseph F. Jr., Christian M. Ringle, dan Marko Sarstedt. (2011). PLS-SEM: Indeed A Silver Bullet. Journal of Marketing Theory and Practice 19:139-13.

Hair, Joseph F. Jr., G. Tomas M. Hult, Christian M. Ringle, dan Marko Sarstedt. (2014). A Primer on Partial Least Squares Structural Equation Modeling (PLS-SEM). United States of America: SAGE Publications, Inc. Kindle Edition.

Kandasami, C. (2014). Impact of Customer Brand Perceived Quality on Buying Intention of Durable Products - A Customers View" International Journal of Management and Social Science Research Review. vol 1 (3), p.1-5.
Khatib, Fahed. (2016). The Impact of Social Media Characteristics on Purchase Decision Empirical Study of Saudi Customers in Aseer Region. International Journal of Business and Social Science. vol 7 (4), p.41-50.

Kotler, Philip. (2011). Manajemen Pemasaran di Indonesia : Analisis, Perencanaan, Implementasi dan Pengendalian. Jakarta : Penerbit Salemba Empat.

Kotler, Philip dan Gary Armstrong. (2012). Prinsip-prinsip Pemasaran Edisi 13. Jakarta: Erlangga.

Kotler, Philip dan Kevin L. Keller. (2012). Marketing Management: $14^{\text {th }}$ Edition. New Jersey: Prentice Hall, Pearson Hall, Pearson Education, Inc.

Munifah, Nur, Endah Pri Ariningsih, dan Wijayanti. (2014). Pengaruh Inovasi Produk dan Harga Produk Terhadap Keputusan Pembelian Smartphone Blackberry di Kalangan Mahasiswa Universitas Muhammadiyah Purworejo. Purworejo. Universitas Muhammadiyah

Tjiptono, Fandy. (2005). Pemasaran Jasa. Malang: Bayu Media Publishing.

Umaternate, Maulana; Willem JF.Alfa Tumbunan, Rita Taroreh. (2014). Promosi, Harga, dan Inovasi Pengaruhnya Terhadap Keputusan Pembelian Sepatu Futsal Nike di Toko Akbar Ali Sport Manado". Jurnal EMBA. vol 2 (2), p.13811392.

Yee, Choy John; San, Ng Cheng \& Khoon, Ch'ng Huck. (2011). Consumers' Perceived Quality, Perceived Value, and Perceived Risk Toward Purchase Decision on Automobile. American Journal of Economics and Business Administration. vol 3 (1), p.47-57

Yogesh, Funde dan Yesha, Mehta. (2014). Effect of Social Media on Purchase Decision. Pacific Business Review International. vol 6 (11), p.45-51 
Fernandes, et.al. (2014). A Comparative Study of Work Values between Generation $X$ and Generation $Y$. Diakses pada 23 Januari 2014, dari http://seanlyons.ca/wpcontent/uploads/2012/01/Fernande s-et-al-2012.pdf

Gary, Yukl. (2001). Kepemimpinan Dalam Organisasi. $5^{\text {th }}$ Ed. Pearson. (2013). Leadership in Organization. $8^{\text {th }}$ Ed. Pearson.

Hersey, P., K.H. Blanchard, dan D.E. Johnson. (2007). Management of Organizational Behavior: Leading Human Resources. Prentice Hall.

Ihalauw, John JOI. (2008). Konstruksi Teori: Komponen dan Prose. Jakarta: Grasindo. (2016). Dari Realitas Bisnis Ke Teori Mini. Jakarta: UBM.

International, Robert Half. (2008). What millennial workers want: How to attract and retain Gen $Y$ employees. Diambil dari http://www.hotjobsresources.com/p dfs/MillennialWorkers.pdf

Jonker, J., dan B. Pennink. (2010). The essence of Reseach Methodology. Springer.

Kartono, Kartini. (2008). Pemimpin dan kepemimpinan. Jakarta: Raja Grafindo Persada.
Lancaster, L.C., dan D. Stillman. (2002). When Generations Collide: Who They Are. Why They Clash.How to Solve the Generational Puzzle at Work. New York: Harper Collins Publishers.

Mujtaba. (2010). Cross-Cultural Value Differences of Working Adult Gen $\mathrm{X}$ and Gen $\mathrm{Y}$ Respondents in Thailand. Volume 1, No.1. 22 Januari 2014

Robbins , S.P., dan T.A. Judge. (2015). Organizational Behavior. $16^{\text {th }}$ Ed. Pearson.

Strauss, W., dan N. Howe. (2000). Millennials Rising: The next great generation, Cartoons by R.J. Matson. New York: Vintage Original.

Suyanto, Bagong. (2005). Metode Penelitian Sosial: Bergabai Alternatif Pendekatan. Jakarta: Prenada Media.

The Millennial Leadership Survey. (2015). Diambil dari www.workplacetrends.com

Thoha, Miftah. (2010). Kepemimpinan Dalam Manajemen. Jakart: Rajawali Pers.

Three Traits Shared by Gen Y Leaders. (2013). Diambil dari www.businessinsider.com

Wijaya, B.R., dan S. Supardo. (2006). Kepemimpinan Dasar-Dasar Dan Pengembangannya. Yogyakarta: Penerbit Graha Ilmu. 